\title{
Morphometric and Meristic Differences among Bluehead Suckers, Flannelmouth Suckers, White Suckers, and Their Hybrids: Tools for the Management of Native Species in the Upper Colorado River Basin
}

\author{
Michael C. Quist* \\ Iowa State University, Department of Natural Resource Ecology and Management, \\ 339 Science II, Ames, Iowa 50011, USA \\ Michael R. Bower \\ U.S. National Park Service, Death Valley National Park, \\ Post Office Box 579, Death Valley, California, 92328, USA
}

Wayne A. Hubert

U.S. Geological Survey, Wyoming Cooperative Fish and Wildlife Research Unit, University of Wyoming, Department 3166, 1000 East University Avenue, Laramie, Wyoming 82071, USA

Thomas L. Parchman and David B. McDonald

Department of Zoology and Physiology, University of Wyoming, Department 3166, 1000 East University Avenue, Laramie, Wyoming 82071, USA

\begin{abstract}
Hybridization with nonnative fishes is a major factor influencing the status of native catostomids in the Colorado River basin. In Wyoming, hybridization with nonnative white suckers Catostomus commersonii is a particular concern in the conservation of native bluehead suckers $C$. discobolus and flannelmouth suckers $C$. latipinnis. The purpose of this study was to describe the meristic and morphometric characteristics of bluehead suckers, flannelmouth suckers, white suckers, and their hybrids from Muddy Creek, Wyoming, for which genotypic data were available to verify the classification of individual fish as pure species or hybrids. We also sought to develop discriminant function models that can be used in the field. Bluehead suckers and flannelmouth suckers had more lateral line scales, shorter and narrower heads, and narrower caudal peduncles than white suckers. Bluehead suckers and bluehead sucker $\times$ white sucker hybrids had a cartilaginous biting ridge in their mouth. Important characteristics for discriminating among these taxa included the number of postdorsal lateral line scales and the exterior width of the mouth. The discriminant function correctly classified $100 \%$ of the bluehead suckers and bluehead sucker $\times$ white sucker hybrids. Flannelmouth suckers, white suckers, and flannelmouth sucker $\times$ white sucker hybrids lacked a cartilaginous biting ridge. The number of postdorsal scales, caudal peduncle depth, and ratio of mouth length to the interior width of the mouth discriminated among taxa without a ridge. The discriminant function correctly classified $100 \%$ of the flannelmouth suckers, $92 \%$ of the white suckers, and $91 \%$ of the flannelmouth sucker $\times$
\end{abstract}

* Corresponding author: mcquist@iastate.edu

Received April 22, 2008; accepted August 31, 2008 Published online April 20, 2009 white sucker hybrids. None of the white suckers or flannelmouth sucker $\times$ white sucker hybrids were misclassified as flannelmouth suckers. Our results suggest that native bluehead suckers and flannelmouth suckers, nonnative white suckers, and hybrids of these species can be accurately identified by a few, easily measured meristic and morphometric characteristics.

Fish represent one of the most imperiled vertebrate groups in North America (Master 1990, 1991; Richter et al. 1997). Moyle and Leidy (1992) estimated that about $20 \%$ of the world's freshwater fishes are extinct or in serious decline, and although the distribution and abundance of native fishes have declined across North America, a large proportion of these fishes are from the western United States (Sheldon 1988; Williams et al. 1989). For instance, $63 \%$ of California's fish species and subspecies are declining, endangered, or extinct (Moyle and Williams 1990), and nearly all fishes endemic to the Colorado River basin have experienced reductions in distribution and abundance, and some have become locally extinct (Mueller and Marsh 2002; Minckley et al. 2003). Habitat loss and degradation are often cited as the most important causes of reductions in aquatic biodiversity (Richter et al. 1997; Wilcove et al. 1998), but interactions with nonnative species (i.e., indigenous and nonindigenous) are also considered a primary cause of species declines and a major hindrance to future conservation efforts (e.g., Minckley et al. 2003; Quist and Hubert 2004). Although habitat modifications and competition with and predation by 
nonnative fishes have influenced the distribution and abundance of native species in North America, a greater threat to many native fishes is hybridization (Rhymer and Simberloff 1996; Allendorf et al. 2001; Perry et al. 2002).

Like many native fishes across North America, those in the Colorado River basin have experienced significant reductions in distribution and abundance. Nearly all of the native fishes in the basin are protected in some form by state agencies, and many are under federal protection (Minckley and Deacon 1991; Minckley et al. 2003). Two species, the flannelmouth sucker Catostomus latipinnis and bluehead sucker $C$. discobolus, are of particular conservation concern (Bezzerides and Bestgen 2002). In Wyoming, the Wyoming Game and Fish Department (WGFD) considers these species to be rare and suffering from deteriorating habitat. The U.S. Bureau of Land Management considers both species "sensitive" in Wyoming, and the Wyoming Natural Diversity Database describes both the bluehead sucker and flannelmouth sucker as species "vulnerable to extinction." Hybridization and its attendant introgression are one of the most important threats to the persistence of flannelmouth and bluehead suckers in the Colorado River basin (Bezzerides and Bestgen 2002), as illustrated by hybridization between these taxa and introduced white suckers in Muddy Creek (Bower 2005; Compton 2007; McDonald et al. 2008).

Muddy Creek, located in south-central Wyoming, is a tributary to the Little Snake River. The creek is an area of high conservation value for native fishes because it historically contained populations of Colorado River cutthroat trout Oncorhynchus clarkii pleuriticus and currently contains sympatric populations of roundtail chub Gila robusta, bluehead suckers, and flannelmouth suckers. Nonnative fishes have had a significant influence on native fishes in Muddy Creek (Bower 2005; Compton 2007). Brook trout Salvelinus fontinalis have replaced cutthroat trout in headwater areas of the watershed. Warmwater sections of Muddy Creek were historically dominated by roundtail chub, bluehead sucker, and flannelmouth sucker, but nonnative creek chub Semotilus atromaculatus and white suckers $C$. commersonii have invaded (Quist et al. 2006b). Creek chub consume and probably compete with native species (Quist et al. 2006a), while white suckers hybridize extensively with the native catostomids (Bezzerides and Bestgen 2002; McDonald et al. 2008).

Native catostomid conservation efforts in the Colorado River basin will probably include selective removal of white suckers and their hybrids, similar to efforts aimed at restoring cutthroat trout populations (e.g., Thompson and Rahel 1996). Selective removal efforts are already being discussed for Muddy Creek. Consequently, fishery managers are in need of tools that allow for discrimination of native suckers from white suckers and their hybrids in the field. The purpose of this study was to describe the meristic and morphometric characteristics of flannelmouth suckers, bluehead suckers, white suckers, and their hybrids in Muddy Creek and to develop models that can be used to discriminate among taxa.

\section{Methods}

Catostomids were sampled from Muddy Creek during the summer of 2003 by means of electrofishing and seining, given a preliminary field identification, and measured to the nearest millimeter (total length [TL]). The same biologist made all preliminary identifications. A small piece of the pelvic fin was clipped and stored in $90 \%$ ethanol for genetic analysis. Fish were then euthanatized, placed on ice, and transported to the laboratory, where they were immediately frozen. Although mountain suckers $C$. platyrhynchus are present in the watershed, they were not included in this analysis. Mountain suckers occur at higher elevations than other catostomids in the basin and, thus, typically exhibit little or no overlap in distribution with other native catostomids (Quist et al. 2006b).

We examined 8 meristic and 10 morphometric characters for each specimen according to Koster (1957), Sigler and Miller (1963), and Baxter and Stone (1995). Meristic characters included the dorsal and anal fin rays and the predorsal, middorsal, and postdorsal lateral line scales. The presence or absence of a cartilaginous biting ridge inside the mouth was recorded for each fish. In addition, a score was given to each fish to reflect the characteristics of its lateral notches (i.e., the shallow grooves that separate the upper and lower lips on either side of the mouth; Baxter and Stone 1995; Bezzerides and Bestgen 2002). If there were no signs of lateral notches, a value of 0 was given to the specimen; if there were lateral notches that clearly separated the upper and lower lips, a value of 2 was given; and if notches were present but they did not completely separate the upper and lower lips, a value of 1 was given. Morphometric characters included the lengths of the snout, naris, and head; the widths of the head and isthmus; the depths of the head and caudal peduncle; the length of the mouth (measured as the distance from the anterior edge of the mouth to the posterior edge of the lower lip); and the interior and exterior widths of the mouth. All measurements were made with digital calipers to the nearest $0.001 \mathrm{~mm}$. In addition, the standard length (SL 
$[\mathrm{mm}])$ of each specimen was measured on a measuring board.

Four hundred sixty-seven amplified fragment length polymorphism (AFLP) markers were used to genetically characterize all sampled bluehead suckers, flannelmouth suckers, white suckers, and their hybrids (hybrids are considered here as both $F_{1}$ and backcrossed individuals; McDonald et al. 2008). Using the fragment frequencies for each of the three sets of phenotypically judged pure species, we calculated likelihoods as the natural logarithms of the product of the fragment frequencies for all 467 loci, in a manner analogous to the allelic assignment test of Paetkau et al. (1995). Thus, each individual had a likelihood score for each of the three pure forms. The resulting threedimensional data were then reduced to two dimensions by principal components analysis (principal component axes 1 and 2 captured $98 \%$ of the variance). All but one of the phenotypically pure representatives of the three parental species fell into widely separated and completely nonoverlapping clusters in the principal components space, and the hybrids formed clusters intermediate to their parental species (McDonald et al. 2008). In addition, the three pure species exhibited substantial genetic differentiation across the AFLP data set (Nei's distance: bluehead sucker versus flannelmouth sucker $=0.25$, bluehead sucker versus white sucker $=0.26$, and flannelmouth sucker versus white sucker $=0.17$ ) and across 600 base pairs (bp) of mtDNA NADH subunit 2 sequences (percent sequence divergence: bluehead sucker versus flannelmouth sucker $=0.130$, bluehead sucker versus white sucker $=0.134$, and flannelmouth sucker versus white sucker $=0.086$ ). Many fragments exhibited fixed differences at individual AFLP loci between pure species but occurred at intermediate frequencies in the hybrids. Field identifications were concordant with the genetic identifications for all fish used in this study, except for a small (159-mm) flannelmouth sucker that was identified in the field as a flannelmouth sucker $\times$ white sucker hybrid. In addition, we excluded fish identified in the field as bluehead sucker $\times$ flannelmouth sucker hybrids $(N=7)$ because the genetic analysis indicated that these fish contained differing proportions of genetic material from all three parental species (McDonald et al. 2008).

A number of techniques are available that adjust morphometric characters to account for size differences among individuals (e.g., Reist 1985), but a simple method that could be used in the field was needed. Therefore, the morphometric characters were sizeadjusted by dividing each measure by the individual's standard length (Harrell and Dean 1988). Size-adjusted data were then used to calculate ratios of morphometric characteristics hypothesized to be important for discriminating among species (e.g., mouth length : head length).

A multivariate analysis of variance (MANOVA) was used to examine whether meristic and morphometric characteristics varied by taxon (Johnson 1998). The MANOVA allowed for testing of differences among taxa without incurring excessive likelihood of type I error. When a difference was detected with MANOVA, one-way analysis of variance (ANOVA) and pairwise comparisons of least-squares means were conducted (Milliken and Johnson 1992). Variables that differed among taxa were considered candidate variables for discriminant function analyses. Candidate variables were then subjected to a backward, stepwise discriminant function analysis (Hurlbut and Clay 1998; Johnson 1998) using $\alpha=0.05$ as the retention criteria. Ideally, a training data set and a test data set would be available for analysis, but the number of specimens that could be sacrificed was limited given the conservation status of the study species. Therefore, classification error was evaluated using a jackknifed cross-validation procedure (Johnson 1998). Specifically, a discriminant function was developed using all of the data, minus the first observation. The function was then applied to the first observation and the accuracy of the classification was recorded. The first observation was added back to the data set, and a discriminant function was then developed using all of the data, minus the second observation. The function was then applied to the second observation and the accuracy of the classification was recorded, etc. Once this procedure was conducted for all observations, the percentage of correct and incorrect classifications was calculated. Reduced models were compared with full models (i.e., models with all variables identified during the stepwise analysis) by using classification rates. A reduced model was only used if the correct classification rate increased for the study species. Although we wanted to ensure that methods were as simple as possible for field use, we also investigated alternative analyses to ensure that the analysis adequately explained patterns in the data. As such, the analysis was conducted using logarithm and square-root-transformed data (Shepard 1991; Sokal and Rohlf 1995) and via a nonparametric discriminant function analysis (Johnson 1998). However, the results of these analyses were nearly identical to those presented in that the same characters were identified and correct classification rates differed by less than $5 \%$ for all taxa. Furthermore, our objective was to provide fisheries scientists with tools (i.e., discriminant functions) that could be used to evaluate a fish's identity in the field. Even if the nonparametric analysis had performed better, nonparametric discriminant tech- 
TABLE 1.-Mean meristic counts and morphometric measurements $(\mathrm{mm})$ for bluehead suckers (BHS), flannelmouth suckers (FMS), white suckers (WHS), and hybrids sampled at Muddy Creek, Wyoming, during 2003. The numbers in parentheses are SEs. Within rows, different letters indicate significant differences $(P<0.05)$.

\begin{tabular}{|c|c|c|c|c|c|}
\hline \multirow[b]{2}{*}{ Characteristic } & \multicolumn{3}{|c|}{ Parental species } & \multicolumn{2}{|c|}{ Hybrids } \\
\hline & BHS & FMS & WHS & BHS $\times$ WHS & FMS $\times$ WHS \\
\hline \multicolumn{6}{|c|}{ Meristic characteristics } \\
\hline Dorsal fin rays & $10.86(0.12) \mathrm{y}$ & $12.00(0.17) \mathrm{z}$ & $11.42(0.15) \mathrm{z}$ & $10.91(0.15) \mathrm{y}$ & $11.71(0.21) \mathrm{z}$ \\
\hline Anal fin rays & $7.05(0.05)$ & $7.00(0)$ & $6.83(0.11)$ & $6.91(0.06)$ & $6.95(0.05)$ \\
\hline Predorsal scales & $49.36(0.65) \mathrm{z}$ & $46.00(1.25) \mathrm{y}$ & $25.58(0.79) \mathrm{w}$ & $31.22(0.56) \times$ & $32.19(0.92) \mathrm{x}$ \\
\hline Middorsal scales & $19.27(0.48) \mathrm{y}$ & $22.08(0.48) \mathrm{z}$ & $13.08(0.61) \mathrm{w}$ & $14.96(0.37) \mathrm{w}$ & $16.48(0.36) \mathrm{x}$ \\
\hline Postdorsal scales & $34.81(0.59) \mathrm{y}$ & $40.92(0.93) \mathrm{z}$ & $25.50(0.67) \mathrm{w}$ & $27.26(0.47) \mathrm{w}$ & $29.67(0.66) x$ \\
\hline Total scales & $103.15(1.26) \mathrm{z}$ & $109.00(1.64) \mathrm{z}$ & $65.17(1.11) \mathrm{w}$ & $73.43(0.93) \times$ & $78.33(1.61) \mathrm{y}$ \\
\hline Cartilaginous ridge & $1.0(0) \mathrm{z}$ & $0(0) \mathrm{y}$ & $0(0) \mathrm{y}$ & $1.0(0) \mathrm{z}$ & $0(0) \mathrm{y}$ \\
\hline Lateral notch & $1.95(0.05) \mathrm{z}$ & $0(0) \mathrm{x}$ & $0(0) \mathrm{x}$ & $0.39(0.10) \mathrm{y}$ & $0(0) x$ \\
\hline \multicolumn{6}{|c|}{ Morphometric characteristics } \\
\hline Snout length & $0.11(0.003) \mathrm{y}$ & $0.10(0.004) \mathrm{y}$ & $0.12(0.003)$ zy & $0.12(0.005) \mathrm{z}$ & $0.12(0.002) \mathrm{z}$ \\
\hline Naris length & $0.08(0.001) \mathrm{y}$ & $0.08(0.003) \mathrm{y}$ & $0.10(0.003) \mathrm{z}$ & $0.09(0.003) \mathrm{z}$ & $0.09(0.002) \mathrm{z}$ \\
\hline Head length & $0.18(0.001) \mathrm{x}$ & $0.19(0.003) \mathrm{y}$ & $0.21(0.006) \mathrm{z}$ & $0.21(0.003) \mathrm{z}$ & $0.21(0.002) \mathrm{z}$ \\
\hline Head width & $0.14(0.002) \mathrm{y}$ & $0.14(0.003) \mathrm{y}$ & $0.16(0.003) \mathrm{z}$ & $0.14(0.004) \mathrm{y}$ & $0.16(0.002) \mathrm{z}$ \\
\hline Head depth & $0.13(0.002) \mathrm{y}$ & $0.15(0.003) \mathrm{w}$ & $0.18(0.003) \mathrm{z}$ & $0.16(0.002) \mathrm{x}$ & $0.17(0.002) \mathrm{y}$ \\
\hline Isthmus width & $0.09(0.002) \mathrm{z}$ & $0.06(0.004) \mathrm{yx}$ & $0.06(0.002) \times$ & $0.07(0.002) \mathrm{y}$ & $0.06(0.002) \mathrm{x}$ \\
\hline Mouth length & $0.07(0.002) \mathrm{yx}$ & $0.08(0.004) \mathrm{z}$ & $0.08(0.003) \mathrm{zy}$ & $0.07(0.002) \times$ & $0.08(0.002) \mathrm{z}$ \\
\hline Interior mouth width & $0.06(0.003) \mathrm{z}$ & $0.05(0.003) \mathrm{x}$ & $0.06(0.003) \mathrm{z}$ & $0.05(0.002) \mathrm{yx}$ & $0.06(0.003) \mathrm{zy}$ \\
\hline Exterior mouth width & $0.09(0.002)$ & $0.09(0.009)$ & $0.09(0.004)$ & $0.08(0.002)$ & $0.09(0.002)$ \\
\hline Caudal peduncle depth & $0.06(0.001) \mathrm{x}$ & $0.07(0.002) \mathrm{x}$ & $0.08(0.001) \mathrm{z}$ & $0.07(0.001) \mathrm{y}$ & $0.08(0.001)$ y \\
\hline
\end{tabular}

niques do not produce equations that can be used in the field (e.g., Douglas et al. 1998).

\section{Results}

In all, 22 bluehead suckers, 12 flannelmouth suckers, 12 white suckers, 23 bluehead sucker $\times$ white sucker hybrids, and 21 flannelmouth sucker $\times$ white sucker hybrids were examined. The bluehead suckers varied in total length from 161 to $254 \mathrm{~mm}$ (mean + SE, $211.3 \pm$ $24.0 \mathrm{~mm}$ ), the flannelmouth suckers from 152 to 405 $\mathrm{mm}(294.2 \pm 79.4 \mathrm{~mm})$, and the white suckers from 196 to $279 \mathrm{~mm}(259.3 \pm 22.4 \mathrm{~mm})$. The bluehead sucker $\times$ white sucker hybrids varied from 133 to 278 $\mathrm{mm}(216.1 \pm 35.6 \mathrm{~mm})$ and the flannelmouth sucker $\times$ white sucker hybrids from 215 to $392 \mathrm{~mm}$ (343.4 \pm $38.2 \mathrm{~mm})$.

Taxa differed with regard to meristic and morphometric characteristics (MANOVA: $F_{68,288}=10.1, P<$ 0.0001). Therefore, one-way ANOVA was conducted to identify differences among taxa (Table 1). Parental species and their hybrids were highly variable with respect to the meristic and morphometric character data. Bluehead suckers had a cartilaginous ridge and well-defined lateral notches; whereas, both flannelmouth suckers and white suckers lacked the ridge and notches. Bluehead suckers and flannelmouth suckers tended to be more similar to each other than to white suckers with respect to nearly all characters. Bluehead suckers and flannelmouth suckers typically had more lateral line scales, shorter and narrower heads, and narrower caudal peduncles than white suckers. Between flannelmouth suckers and bluehead suckers, flannelmouth suckers tended to be most similar to white suckers (Table 1). For example, flannelmouth suckers and white suckers averaged a higher number of dorsal fin rays and had a shorter distance across the isthmus compared with bluehead suckers.

Mantel tests based on matrices of the first principal component explaining morphology and pairwise relatedness estimated from AFLP band profiles $(P=0.002$ based on 5,000 replicates) revealed a high correlation between genetic and morphological divergence, indicating that morphological differences reflect genetic variation among pure species and hybrids. Hybrid catostomids were intermediate to the parental species for nearly all characters (Table 1). The bluehead sucker $\times$ white sucker hybrids were more similar to the bluehead suckers than to the white suckers based on the number of dorsal fin rays and the width of the head. In addition, all of these hybrids had a cartilaginous ridge (Table 1). In contrast, the flannelmouth sucker $\times$ white sucker hybrids were more similar to the white suckers with respect to most characteristics (e.g., total lateral line scales, head characteristics, and caudal peduncle depth).

The discriminant function analysis indicated that a relatively small subset of characters and their ratios discriminated among taxa. Because several taxa had a cartilaginous ridge, analyses were conducted separately using data for taxa with and taxa without a cartilag- 
TABLE 2.-Functions used to discriminate among bluehead suckers (BHS), flannelmouth suckers (FMS), white suckers (WHS), and hybrids from Muddy Creek. The explanatory variables include the number of postdorsal lateral line scales (PDS), caudal peduncle depth (CPD), and the ratio of mouth length to interior mouth width (ML/IMW). The data for each specimen were input into the equations, and the equation with the largest resulting value was deemed to predict species identity.

\begin{tabular}{lc}
\hline \multicolumn{1}{c}{ Species } & \multicolumn{1}{c}{ Function } \\
\hline & Cartilaginous ridge present \\
BHS & $-295.23+10.22 \cdot \mathrm{PDS}+2,563.00 \cdot \mathrm{EMW}$ \\
$\mathrm{BHS} \times$ WHS & $-202.81+8.31 \cdot \mathrm{PDS}+2,182.00 \cdot \mathrm{EMW}$ \\
& Cartilaginous ridge absent \\
FMS & $-160.86+4.49 \cdot \mathrm{PDS}+1,912 \cdot \mathrm{CPD}+8.42 \cdot(\mathrm{ML} / \mathrm{IMW})$ \\
FMS $\times$ WHS & $-139.63+3.21 \cdot \mathrm{PDS}+2,348 \cdot \mathrm{CPD}+4.22 \cdot(\mathrm{ML} / \mathrm{IMW})$ \\
WHS & $-140.62+2.82 \cdot \mathrm{PDS}+2,613 \cdot \mathrm{CPD}-2.51 \cdot(\mathrm{ML} / \mathrm{IMW})$ \\
\hline
\end{tabular}

inous biting ridge. The best characters for discriminating among taxa with a cartilaginous ridge included the number of postdorsal lateral line scales and exterior width of the mouth (Table 2). The discriminant function did an excellent job of discriminating among fish with a biting ridge. Correct classification rates were $100 \%$ for both bluehead suckers and bluehead sucker $\times$ white sucker hybrids. The best characters for discriminating between taxa without a cartilaginous ridge included the number of postdorsal lateral line scales, caudal peduncle depth, and the ratio of mouth length to the interior width of the mouth (Table 2). Like the model for fish with a cartilaginous ridge, the discriminant function for fish lacking a ridge performed well. Correct classification rates were $100 \%$ for the flannelmouth suckers, $92.3 \%$ for the white suckers (the remaining $7.7 \%$ were misclassified as flannelmouth sucker $\times$ white sucker hybrids), and $90.5 \%$ for the flannelmouth sucker $\times$ white sucker hybrids (the remaining $9.5 \%$ were misclassified as white suckers). None of the flannelmouth sucker $\times$ white sucker hybrids or white suckers were incorrectly classified as flannelmouth suckers.

\section{Discussion}

Like other fishes in the western United States, bluehead sucker and flannelmouth sucker are species of high conservation concern because of substantial declines in their distribution and abundance. A recent status review by Bezzerides and Bestgen (2002) found that bluehead suckers occupy only $45 \%$ of their original native habitat and flannelmouth suckers about $50 \%$. A number of factors are related to the decline of these species (e.g., habitat degradation), but hybridization is considered to be a primary impediment to conservation efforts (Bezzerides and Bestgen 2002; Bower 2005). Hybridization is a natural and important mechanism for evolutionary change (Hubbs 1955; Campton and Utter 1985). However, anthropogenic habitat alterations may remove the reproductive barriers that historically existed between sympatric species, thereby increasing hybridization (Echelle 1991; Rhymer and Simberloff 1996; Perry et al. 2002). Direct evidence of such mechanisms from the fisheries literature is rare, but the high proportion of hybridization between pallid sturgeon Scaphirhynchus albus and shovelnose sturgeon S. platorynchus is one example where changes in large-river habitat conditions are hypothesized to have weakened or eliminated reproductive barriers (Keenlyne et al. 1994). Hybridization also results from the translocation of indigenous species (Rhymer and Simberloff 1996; Perry et al. 2002). For instance, introgression of nonnative rainbow trout Oncorhynchus mykiss and cutthroat trout has significantly reduced the genetic integrity of cutthroat trout populations (Allendorf and Leary 1988; Behnke 2002; Quist and Hubert 2004).

Hybridization of bluehead suckers and flannelmouth suckers with nonnative catostomids has been recognized for a long time. A number of scientists have reported hybridization of bluehead suckers with flannelmouth suckers, white suckers, and mountain suckers (e.g., Sigler and Miller 1963; Smith 1966; Holden and Stalnaker 1975a). Flannelmouth suckers have also been reported to hybridize with many species, including Utah suckers Catostomus ardens, desert suckers C. clarkii, white suckers, bluehead suckers, and razorback suckers Xyrauchen texanus (e.g., Hubbs and Hubbs 1947; Sigler and Miller 1963; Holden and Stalnaker 1975a, 1975b; Douglas and Marsh 1998; Bezzerides and Bestgen 2002). Although hybrids have been reported since the 1940s, the occurrence and abundance of hybrid catostomids (primarily white sucker hybrids) have increased dramatically in portions of the upper Colorado River basin over the last several decades (Holden and Stalnaker 1975b; Bestgen and Crist 2000; Bezzerides and Bestgen 2002). Recent research has indicated that introgressive hybridization has been so extensive between white suckers and flannelmouth suckers that 
the genetic integrity of flannelmouth suckers has been eroded to the point where they are at risk of local extinction in Muddy Creek (McDonald et al. 2008). This same research has shown that hybridization also occurs between white suckers and bluehead suckers in Muddy Creek; however, hybrids are intermediate with respect to nuclear markers, indicating that backcrossing has probably been less extensive.

Historical data on native suckers and their hybrids are lacking in the Colorado River basin of Wyoming, but recent research suggests that hybrids are widely distributed and locally abundant. Bluehead suckers and flannelmouth suckers were once widespread in the Green River basin (a major tributary to the Colorado River) of Wyoming but have virtually disappeared over the last 50 years (Wheeler 1997). The WGFD recently completed a survey focused on describing the current distribution of native and nonnative fishes in the Colorado River basin of Wyoming. Results of the survey suggest that flannelmouth suckers and bluehead suckers occur in low abundance in a few areas of the upper Colorado River basin; whereas, white suckers are abundant and ubiquitous (Kern et al. 2007). Out of about 14,000 catostomids sampled from the Green River and Little Snake River basins during 2002-2006, less than $1 \%$ were bluehead suckers, $6 \%$ were flannelmouth suckers, and $65 \%$ were nonnative white suckers (K. Gelwicks, WGFD, unpublished information). About $4 \%$ of the catostomids were alleged hybrids, $87 \%$ of which were thought to be flannelmouth sucker $\times$ white sucker hybrids. Similar patterns were recently identified in Muddy Creek. Compton (2007) estimated population densities of native and nonnative fishes in Muddy Creek and found that $26 \%$ of the catostomids were bluehead suckers, less than $1 \%$ were flannelmouth suckers, and about 55\% were white suckers; approximately $13 \%$ of the catostomids were hybrids, $70 \%$ of which were identified as flannelmouth sucker $\times$ white sucker hybrids. In Wyoming, only one known population of flannelmouth suckers that does not occur sympatrically with white suckers is known, which is of special concern in light of genetic data indicating substantial introgression of white sucker genotypes into sympatric flannelmouth sucker populations (McDonald et al. 2008). This lone population occurs in the headwater portion of Bitter Creek where intermittent downstream segments and a road crossing probably act as a barrier to upstream movement of nonnative fishes. The only population of bluehead suckers that does not occur with white suckers was in Ringdahl Reservoir. However, bluehead suckers from this population were relocated to two reservoirs and a pond in 2006 when Ringdahl Reservoir was drained.

The widespread occurrence and high densities of white suckers in the Colorado River basin of Wyoming has led fisheries scientists to consider activities to improve the status of native catostomids in the basin. In many ways, the situation for native catostomids in the Colorado River basin is similar to that for cutthroat trout where extensive introgression with rainbow trout threatens the persistence of cutthroat trout across the western United States (e.g., Behnke 2002; Quist and Hubert 2004). One of the most common active management approaches to cutthroat trout conservation includes the removal of nonnative salmonids and hybrids (e.g., Thompson and Rahel 1996). Depending on the system and conservation goals, fish may be completely or selectively removed from a stream or river (Quist and Hubert 2004). Large-scale efforts where the entire fish assemblage is removed and native fishes are restocked will probably occur for native catostomids in the Colorado River basin, but initial efforts will probably focus on the selective removal of nonnative white suckers and their hybrids. Selective removal efforts will require the rapid and accurate identification of native catostomids species and their hybrids.

Bluehead suckers and flannelmouth suckers have meristic and morphological characteristics typical of other fishes in the Colorado River basin. Streams and rivers across this basin have high salinity, high sediment transport, and extremes in water temperature and flow (e.g., Minckley et al. 1986; Carlson and Muth 1989; Carothers and Brown 1991). Consequently, fish have evolved various morphologies and life histories to contend with the harsh conditions typical of the basin. Minckley et al. (1986) classified the fishes of the Colorado River basin into one of the three categories, one of which was "big-river fishes." This group encompassed endemic fishes that typically occur in the larger systems of the basin. Although bluehead suckers and flannelmouth suckers are found in both large rivers and small streams (e.g., Muddy Creek), they are classified as big-river fishes. Big-river fishes typically have streamlined body forms (e.g., long, slender bodies and small, narrow heads), large falcate fins, thick skin with small and embedded scales, and thin caudal peduncles (Deacon and Minckley 1974; Minckley et al. 1986). These characteristics are probably adaptations to the high flows and sediment levels characteristic of streams and rivers in the Colorado River basin (Minckley et al. 1986). Our results support these generalities in that bluehead suckers and flannelmouth suckers had a large number of small scales and narrow caudal peduncles, and both species had short, narrow heads compared with white suckers. Consequently, meristic and morphometric characteristics successfully segregated bluehead suck- 
ers, flannelmouth suckers, white suckers, and their hybrids.

Discriminating among taxa is necessary for a number of conservation and management actions. Results of this study suggest that native, nonnative, and hybrid catostomids can be accurately identified by determining the presence of a cartilaginous biting ridge, counting postdorsal scales, and taking a few morphological measurements. Field identifications made by a highly experienced biologist were identical to the genetic identifications, except for a small flannelmouth sucker that was misidentified as a flannelmouth sucker $\times$ white sucker hybrid. As new biologists handle these taxa, tools are needed that allow for the accurate identification of fishes in the field. Such tools are not only needed for selective removal efforts, but also for routine monitoring of fish populations, potential relocation of fishes, and creating of captive breeding stocks. The discriminant models developed in this study are one such tool that can be easily applied in the field with the use of a pocket calculator. Although our study focused on catostomids from Muddy Creek, Wyoming, we expect that the models can be applied to other catostomids populations in the upper Colorado River basin.

\section{Acknowledgments}

We thank R. Beatty, M. Gorges, and K. Lang for assistance in the field. Z. Jackson, T. Neebling, G. Smith, and two anonymous reviewers provided helpful comments on a previous version of the manuscript. We also thank T. McClean of the Nucleic Acid Exploration Facility at the University of Wyoming. Funding was provided by the U.S. Bureau of Land Management, U.S. Bureau of Reclamation, and Iowa State University, Department of Natural Resource Ecology and Management. The Wyoming Cooperative Fish and Wildlife Research Unit is jointly sponsored by the U.S. Geological Survey, the University of Wyoming, Wyoming Game and Fish Department, and the Wildlife Management Institute.

\section{References}

Allendorf, F. W., and R. F. Leary. 1988. Conservation and distribution of genetic variation in a polytypic species, the cutthroat trout. Conservation Biology 2:170-184.

Allendorf, F. W., R. F. Leary, P. Spruell, and J. K. Wenburg. 2001. The problems with hybrids: setting conservation guidelines. Trends in Ecology and Evolution 16:56135622.

Baxter, G. T., and M. D. Stone. 1995. Fishes of Wyoming. Wyoming Game and Fish Department, Cheyenne.

Behnke, R. J. 2002. Trout and salmon of North America. Free Press, New York.

Bestgen, K. R., and L. W. Crist. 2000. Response of the Green
River fish community to construction and reregulation of Flaming Gorge Dam, 1962-1996. Final Report to the Colorado River Recovery Implementation Program, Project 40. Larval Fish Laboratory, Department of Fishery and Wildlife Biology, Colorado State University, Contribution 109, Fort Collins.

Bezzerides, N., and K. R. Bestgen. 2002. Status review of roundtail chub Gila robusta, flannelmouth sucker Catostomus latipinnis, and bluehead sucker Catostomus discobolus in the Colorado River basin. Larval Fish Laboratory, Department of Fishery and Wildlife Biology, Colorado State University Contribution 118, Fort Collins.

Bower, M. R. 2005. Distributions and habitat associations of bluehead suckers, flannelmouth suckers, and roundtail chubs in the upper Muddy Creek watershed of southern Carbon County, Wyoming. Master's thesis. University of Wyoming, Laramie.

Campton, D. E., and F. M. Utter. 1985. Natural hybridization between steelhead trout (Salmo gairdneri) and coastal cutthroat trout (Salmo clarki clarki) in two Puget Sound streams. Canadian Journal of Fisheries and Aquatic Sciences 42:110-119.

Carlson, C. A., and R. T. Muth. 1989. Colorado River: lifeline of the American Southwest. Canadian Special Publication of Fisheries and Aquatic Sciences 106.

Carothers, S. W., and B. T. Brown. 1991. The Colorado River through Grand Canyon: natural history and human change. University of Arizona Press, Tucson.

Compton, R. I. 2007. Population fragmentation and white sucker introduction affect populations of bluehead suckers, flannelmouth suckers, and roundtail chubs in a headwater stream system, Wyoming. Master's thesis. University of Wyoming, Laramie.

Deacon, J. E., and W. L. Minckley. 1974. Desert fishes. Pages 385-488 in W. Brown, Jr., editor. Desert biology, volume 2. Academic Press, New York.

Douglas, M. E., and P. C. Marsh. 1998. Population and survival estimates of Catostomus latipinnis in northern Grand Canyon, with distribution and abundance of hybrids with Xyrauchen texanus. Copeia 1998:915-925.

Douglas, M. E., R. R. Miller, and W. L. Minckley. 1998. Multivariate discrimination of Colorado Plateau Gila spp.: the "art of seeing well" revisited. Transactions of the American Fisheries Society 127:163-173.

Echelle, A. A. 1991. Conservation genetics and genic diversity in freshwater fishes of western North America. Pages 141-153 in W. L. Minckley and J. E. Deacon, editors. Battle against extinction: native fish management in the American West. University of Arizona Press, Tucson.

Harrell, R. M., and J. M. Dean. 1988. Identification of juvenile hybrids of Morone based on meristics and morphometrics. Transactions of the American Fisheries Society 117:529-535.

Holden, P. B., and C. B. Stalnaker. 1975a. Distribution and abundance of mainstream fishes of the middle and upper Colorado River basins, 1967-1973. Transactions of the American Fisheries Society 104:217-231.

Holden, P. B., and C. B. Stalnaker. 1975b. Distribution of fishes in the Dolores and Yampa river systems of the 
upper Colorado River basin. Southwestern Naturalist 19:403-412.

Hubbs, C. L. 1955. Hybridization between fish species in nature. Systematic Zoology 4:1-20.

Hubbs, C. L., and L. C. Hubbs. 1947. Natural hybrids between two species of catostomid fishes. Papers of the Michigan Academy of Science, Arts and Letters 31:147-167.

Hurlbut, T., and D. Clay. 1998. Morphometric and meristic differences between shallow- and deep-water populations of white hake (Urophycis tenuis) in the southern Gulf of St. Lawrence. Canadian Journal of Fisheries and Aquatic Sciences 55:2274-2282.

Johnson, D. E. 1998. Applied multivariate methods for data analysts. Duxbury Press, Pacific Grove, California.

Keenlyne, K. D., L. K. Graham, and B. C. Reed. 1994. Hybridization between the pallid and shovelnose sturgeons. Proceedings of the South Dakota Academy of Science 73:59-67.

Kern, A., R. Keith, and K. Gelwicks. 2007. Green River watershed native nongame species research: phase II. Progress report to the U.S. Bureau of Reclamation, agreement 02-FC-40-6870. Wyoming Game and Fish Department, Green River.

Koster, W. J. 1957. Guide to the fishes of New Mexico. University of New Mexico Press, Albuquerque.

Master, L. L. 1990. The imperiled status of North American aquatic animals. Biodiversity Network News 3:7-8.

Master, L. L. 1991. Assessing threats and setting priorities for conservation. Conservation Biology 5:559-563.

McDonald, D. B., T. L. Parchman, M. R. Bower, W. A. Hubert, and F. J. Rahel. 2008. An introduced and a native vertebrate hybridize to form a genetic bridge to a second native species. Proceedings of the National Academy of the Sciences of the USA 105:10837-10842.

Milliken, G. A., and D. E. Johnson. 1992. Analysis of messy data, volume I. Designed experiments. Chapman and Hall, New York.

Minckley, W. L., and J. E. Deacon, editors. 1991. Battle against extinction: native fish management in the American West. University of Arizona Press, Tucson.

Minckley, W. L., D. A. Hendrickson, and C. E. Bond. 1986. Geography of western North American fishes: description and relationships to intracontinental tectonism. Pages 519-613 in C. H. Hocutt and E. O. Wiley, editors. The zoogeography of North American freshwater fishes. Wiley, New York.

Minckley, W. L., P. C. Marsh, J. E. Deacon, T. E. Dowling, P. W. Hedrick, W. J. Matthews, and G. Mueller. 2003. A conservation plan for native fishes of the lower Colorado River. BioScience 53:219-234.

Moyle, P. B., and R. A. Leidy. 1992. Loss of biodiversity in aquatic ecosystems: evidence from fish faunas. Pages 127-169 in P. L. Fielder and S. K. Jain, editors. Conservation biology: the theory and practice of nature conservation, preservation, and management. Chapman and Hall, New York.

Moyle, P. B., and J. E. Williams. 1990. Biodiversity loss in the temperate zone: decline of the native fish fauna of California. Conservation Biology 4:475-484.

Mueller, G. A., and P. C. Marsh. 2002. Lost: a desert river and its native fishes-a historical perspective of the lower Colorado River. U.S. Government Printing Office,
Information and Technology Report ISGS/BRD/ITR2002-0010, Denver.

Paetkau, D., W. Calvert, I. Stirling, and C. Strobeck. 1995. Microsatellite analysis of population structure in Canadian polar bears. Molecular Ecology 4:347-356.

Perry, W. L., D. M. Lodge, and J. L. Feder. 2002. Importance of hybridization between indigenous and nonindigenous freshwater species: an overlooked threat to North American biodiversity. Systematic Biology 51:255-275.

Quist, M. C., M. R. Bower, and W. A. Hubert. 2006a. Summer food habits and trophic overlap of roundtail chub and creek chub in Muddy Creek, Wyoming. Southwestern Naturalist 51:22-27.

Quist, M. C., M. R. Bower, W. A. Hubert, and F. J. Rahel. 2006b. Spatial patterns of fish assemblage structure in a tributary system of the upper Colorado River basin. Journal of Freshwater Ecology 21:673-680.

Quist, M. C., and W. A. Hubert. 2004. Bioinvasive species and the preservation of cutthroat trout in the western United States: ecological, social, and economic issues. Environmental Science and Policy 7:303-313.

Reist, J. D. 1985. An empirical evaluation of several univariate methods that adjust for size variation in morphometric data. Canadian Journal of Zoology 63:1429-1439.

Richter, B. D., D. P. Braun, M. A. Mendelson, and L. L. Master. 1997. Threats to imperiled freshwater fauna. Conservation Biology 11:1081-1093.

Rhymer, J. M., and D. Simberloff. 1996. Extinction by hybridization and introgression. Annual Review of Ecology and Systematics 27:83-109.

Sheldon, A. L. 1988. Conservation of stream fishes: patterns of diversity, rarity, and risk. Conservation Biology 2:149-156.

Shepard, G. 1991. Meristic and morphometric variation in black sea bass north of Cape Hatteras, North Carolina. North American Journal of Fisheries Management 11:139-148.

Sigler, W. F., and R. R. Miller. 1963. Fishes of Utah. Utah State Department of Fish and Game, Salt Lake City.

Smith, G. R. 1966. Distribution and evolution of North American catostomids fishes of the subgenus Pantosteus, genus Catostomus. Miscellaneous Publications Museum of Zoology University of Michigan 129.

Sokal, R. R., and F. J. Rohlf. 1995. Biometry, 3rd edition. Freeman, New York.

Thompson, P. D., and F. J. Rahel. 1996. Evaluation of depletion-removal electrofishing of brook trout in small rocky mountain streams. North American Journal of Fisheries Management 16:332-339.

Wheeler, C. A. 1997. Current distributions and distributional changes of fish in Wyoming west of the Continental Divide. Master's thesis. University of Wyoming, Laramie.

Wilcove, D. S., D. Rothstein, J. Dubow, A. Phillips, and E. Losos. 1998. Quantifying threats to imperiled species in the United States. BioScience 48:607-615.

Williams, J. E., J. E. Johnson, D. A. Hendrickson, S. Contreras-Balderas, J. D. Williams, M. Navarro-Mendoza, D. E. McAllister, and J. E. Deacon. 1989. Fishes of North America: endangered, threatened, or of special concern. Fisheries 14(6):2-20. 